Historic, Archive Document

Do not assume content reflects current scientific knowledge, policies, or practices. 



\section{RETURA TO POMOLOGY}

SECTION OF NOWENCLATURE.

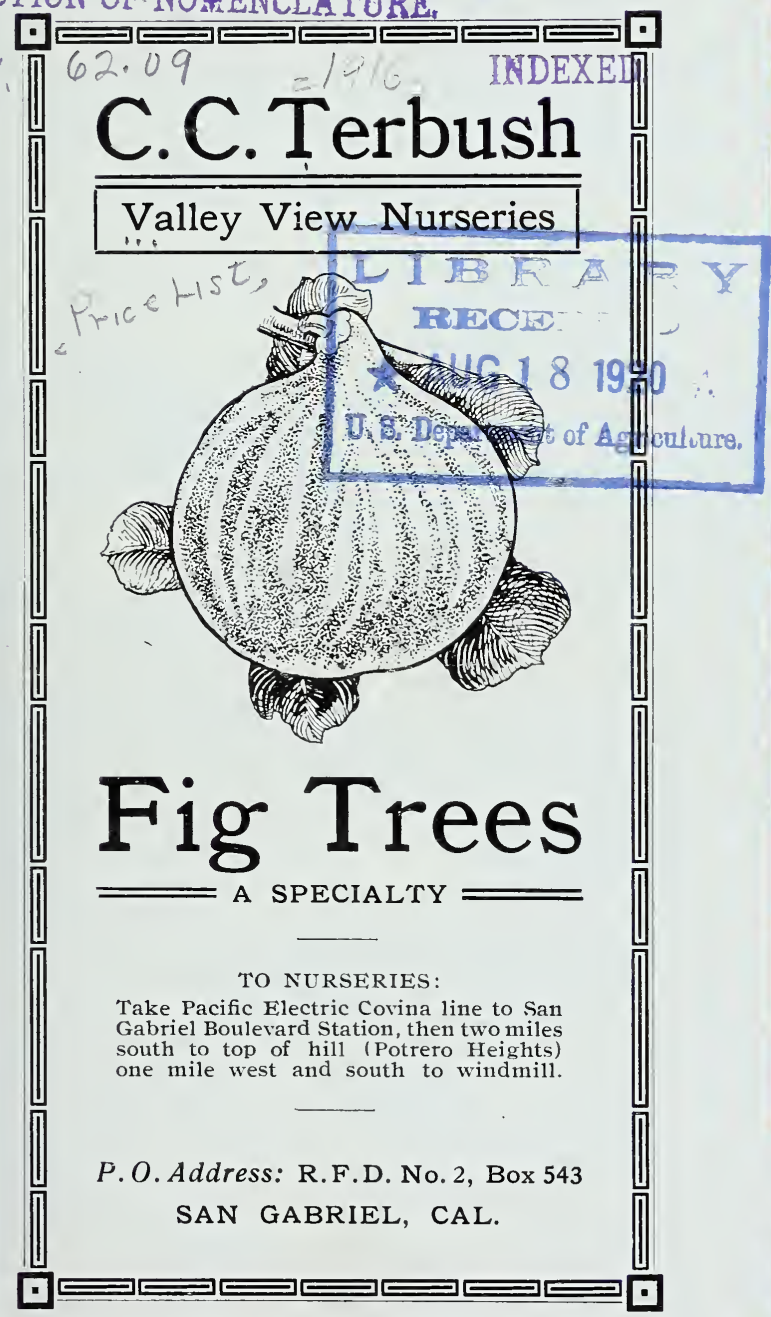




\section{PRICE LIST}

2 year old, straight and branched

\begin{tabular}{|c|c|c|c|}
\hline Size & Each & 10 & 100 \\
\hline $2 \mathrm{ft}$. & $20 c$ & $\$ 1.50$ & $\$ 10.00$ \\
\hline $3 \mathrm{ft}$. & $25 c$ & 2.00 & 1200 \\
\hline $4 \mathrm{ft}$. & $35 c$ & 3.00 & 1500 \\
\hline $5 \mathrm{ft}$. & $40 c$ & 3.50 & 20.00 \\
\hline $6 \mathrm{ft}$. & $50 c$ & 4.00 & 250 \\
\hline
\end{tabular}

Ten per cent discount on lots of 500 or more. All trees are straight and well rooted.

\section{VARIETIES}

White Adriatic. Large, skin greenish yellow. Pulp red; extensively planted for drying purposes.

Kadota. A white fig of medium size; rich flavor; one of the best for table uses; very prolific; trees bearing quite young.

Calimyrna. Large size, skin lemon yellow, pulp reddish amber, flavor and quality unsurpassed. To raise successfully it is necessary to have the aid of the capri fig to carry the fig wasp

White Pacific. Medium to large, skin greenish yellow, pulp light yellow and very sweet, heavy bearer.

Brown Ischia. A medium size brown fig, Pyriform when fully ripe, of a deep brownish red color, trees especially valuable as a shade tree, its crown forming a fine umbrella, with densest shade.

Brown Turkey. Sometimes called "Brown Ischia." This is a very large fig, color violet brown, cne of the earliest. 


\section{MAY $4-1916$}

Brunswick. Extra large, short neck making it nearly round, skin bluish black.

Panacha. The most ornamental of all Fig trees, branches marked with green and yellow stripes, fruit medium size, pyriform, pulp sweet, fruit also marked with green and yellow stripes.

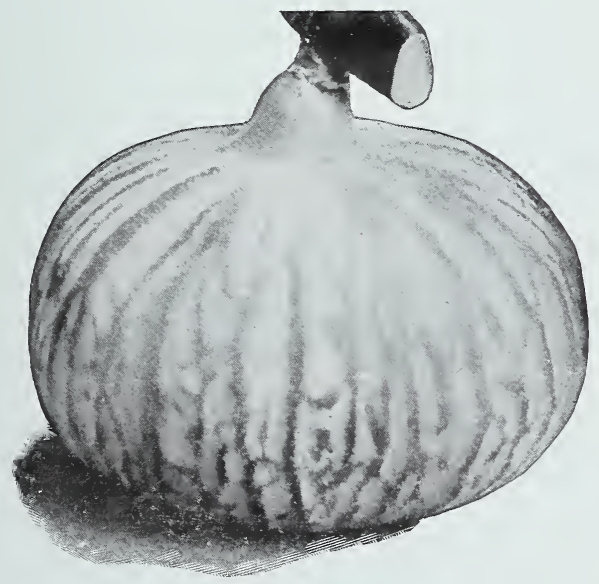

Rose Blanche. Fruit medium oblate, skin thin, deep purple, pulp deep red, valuable for table or drying.

Mission. (California's Black.) The large black fig most common in Calitornia, a great grower and a heavy producer and one of the best. Ripens June and August.

Grise. Medium, oblong; no neck; skin light blue; pulp rose color, very sweet, excellent for the table. 
Cernica. Fruit medium, skin deep purple, pulp deep carnation red, trees of drooping habit.

Verdal Longue. Fruit large turbinate, skin green when ripe, pulp carnation red, color very rich, trees of drooping habit.

Black San Pedro. Very large, no stalk, skin violet black with green neck, pulp red, one of the largest; excellent for the table.

White Smyrna. A compact grower of spreading habit, thin skin, greyish green color, an excellent table fig.

White Celest. A very small fig of amber color, fine for preserves.

Caprifig. Must be grown in connection with the Calimyrna (Smyrna) fig. Plant in groups by themselves, very desirable as a shade tree, the the ratio being one Capri to twenty-five Smyrnas.

\section{WALNUT TREES}

Grafted - one year old.

Placentia Perfection.

Size

4 to $6 \mathrm{ft}$. $\$ 4000$

6 to $8 \mathrm{ft}$ 50.00

8 to $10 \mathrm{ft}$. 75.00

$10 \mathrm{ft}$. up

90.00

IMPORTANT NOTICE. I exercise due care to keep all varieties TRUE, to name, and hold myself in readiness at any time to replace, on proper proof, any stock that may proof otherwise; but it is mutually agreed between the purchaser and myself that I shall not at any time be liable for any amount greater than the original price of the stock. All sales made subject to stock being unsold when order is received, or loss by any and all unavoidable causes. 